\title{
Immigrant Entrepreneurs and Their Perceived Success in Small Retail Businesses: Preliminary New Zealand Findings
}

\author{
Pieter Nel${ }^{\star}$ and Moha Abdullah**
}

\begin{abstract}
As international migration continues to be a significant force in globalization, some migrants are forced by circumstances to migrate. Others are attracted by the prospects of greater economic, social, and educational opportunities for themselves and their families. Whilst many migrants take up positions in paid employment, a considerable proportion of them migrate specifically to initiate new venture start-up activities. This study highlights preliminary findings on attributes and essential elements of immigrant entrepreneurs, their issues and how they perceived their business success in small retail business. A survey comprising 262 immigrant entrepreneur respondents in Auckland, New Zealand was executed. The study found that about 40 percent had prior business experience before migrating to New Zealand with more than 30 percent migrating with a business visa. An ANOVA test conducted confirms that there are certain issues such as local business regulations, access to capital, advisory services, training facilities and access to suppliers that are important factors contributing to the perceived business success among immigrant entrepreneurs. The outcome of the study will help the training and development authorities to take the necessary steps to outline a new and productive content for potential entrepreneurial development.
\end{abstract}

Keywords: Immigrant entrepreneurs, small business, Auckland

Field of Research: small business, entrepreneurship

\section{Introduction}

As international migration continues to be a significant force in globalisation, some migrants are forced by circumstances to migrate. Others are attracted by the prospect of greater economic, social and educational opportunities for themselves and their families. Whilst many migrants take up positions in paid employment, a considerable proportion migrate specifically to initiate new venture and start-up business activities. The literature tends to suggest that there are two different views of the migratory pathways of immigrant entrepreneurs.

Firstly, immigrants who are driven by the basic economic circumstances, i.e. when expected income and profits attract their attention to migration. This type of migration relates to "push-pull factors" of spatial imbalances in the distribution of production factors that force them to leave their place of origin, with higher expected income and living standards in the country of destination. In this pathway, migrants offering technical skills and other skilled workers as well as unskilled labour participate. Ideally their success depends on the availability of jobs. As job opportunities are not easily secured, they end up by venturing into small business activities. The second pathway is a special category of entrepreneurial migration. Migrants who are included under this pathway have special characteristics in that they have business experience and management skills as basic sources of their entrepreneurial activities in the destination country. In this case, they search for the best place that offers opportunities for profit, create their own jobs and employment for others. The presence and contribution of immigrant entrepreneurs are expected to create and generate greater

\footnotetext{
*Prof. Pieter Nel, Department of Management and Marketing, Unitec Institute of Technology, Auckland, New Zealand. Email: pnel@unitec.ac.nz

**Prof. Moha Abdullah. Department of Management, International Islamic University of Malaysia, Kuala Lumpur, Malaysia. E-mail: mosri@iium.edu.my
} 
economic prosperity and better job creation in the countries they emigrate to (Ribeiro-Soriano \& Mas-Verdú, 2015). The benefits of having immigrant entrepreneurs in the host country such as physical capital investment, job creation for local workers and contribution towards the country's GDP receive considerable recognition (Lin, 2015). Note that efforts to attract global immigrant entrepreneurs have not been limited to developed countries but developing countries as well.

Research on the impact of immigration has traditionally been focussed on social experience as well as psychological perspectives of individual immigrants and/or their families. Relatively limited attempts have been made to focus on understanding how individuals experience the establishing, managing and developing of small business activities in countries they migrated to. Against this trend, there is limited information available on their involvement in small retail business activities. Their background, types and characteristics of business activities, status, problems and challenges as well as business success have only been superficially explored. Understanding these issues will not only fill a vacuum or gap of knowledge in the literature but, more essentially, will contribute to devising appropriate and effective strategies regarding immigrant entrepreneurs.

The primary aim of this paper is to present preliminary findings on the involvement of immigrant entrepreneurs in small retail business activities based on a survey carried out in Auckland city, New Zealand, from June to October 2015. These include characteristics of immigrant entrepreneurs, features of their enterprises, challenges faced by them and their perceived business success in Auckland city.

To complement its objectives, this paper is organised into several sections such as a literature review, methodology and findings as well as a summary and conclusions. After the introductory part, the literature section reviews and evaluates empirical research which is related to the current study. The methodology is then presented. The preliminary findings show clear characteristics of immigrant entrepreneurs and their enterprises. The last section summarises the findings and outlines some of the implications.

\section{Literature Review on Immigrant Entrepreneurs}

\subsection{Immigrant Entrepreneurs and their Characteristics}

Though immigrant entrepreneurs have not been widely studied, their presence is increasingly recognised globally. Involvement of immigrants in businesses is known as "immigrant entrepreneurs" and they are defined as "individuals who establish their business outside their home countries or immigrate to a new country" (Yu 2014). Opportunities for immigrant entrepreneurs are also provided by certain host governments to facilitate small enterprises enabling immigrants to apply for limited funds along with technical resources to start a small venture (Waldinger, Ward, \& Aldrich, 2000). Countries, notably Canada, Australia and New Zealand, have a positive approach and are more receptive towards international migration than most other countries. 
The literature suggests that there are certain characteristics of immigrant entrepreneurs who tend to be more successful than others. According to Bates (1999), educated entrepreneurs have more business success and opportunities than those with lesser educational qualifications. Conversely, certain professions, which do not require extensive educational qualifications, have attracted more attention from less educated immigrants. Small businesses like catering, child care centres and garment firms have a huge influx and prospects for immigrant entrepreneurs (Kloosterman, Van der Leun, \& Rath, 1998).

This social embeddedness, market orientation and new business development are challenging areas for low skilled immigrants compared to skilled immigrant entrepreneurs (Wadhwa, Saxenian, Rissing, \& Gereffi, 2007). The studies in terms of business growth have found that skilled immigrants are ahead of unskilled or poorly trained immigrants especially in the services sectors (Alam \& Hoque, 2010).

Besides family support, technological factors also play an important role in the success of immigrant enterprises. Those entrepreneurs who use contemporary technological advances have surpassed those entrepreneurs who are less reliant on the use of information and technology (Hart \& Acs, 2011).

\subsection{Immigrant Entrepreneurs in New Zealand. Their Issues and Business Success.}

While it is difficult to determine the exact number of immigrant entrepreneurs in New Zealand, it is well noted that New Zealand is one of the best recipient countries of immigrants in the world.

Since New Zealand passed a new Immigration Act in 1987, the preference for migrants from Britain, Europe or Northern America based on their race was reviewed, and has instead classified migrants on their skills, personal qualities, and potential contribution to New Zealand's economy and society (Immigration New Zealand, 2015). Regulations require immigrants to be of good character, resulting in the emergence of immigrants who have come from non-traditional sources, particularly from Asia and other parts of the world. It is recorded that in 2005, almost $20 \%$ of New Zealanders had been born overseas, which is one of the highest percentages of any country in the world. The figures also show that there was a 21 per cent rise in work permits issued in the 2005/06 year compared with the previous year. According to Immigration New Zealand, nearly 100,000 people were issued work permits to work in sectors ranging from information technology to horticulture in the 2005/06 year. Meanwhile, a total of 52,000 people were approved for permanent New Zealand residence in the two years of 2005-2006. Over 60 per cent were approved under the skilled or business categories. A revised Immigration Act 2007 allows a total amount of NZ\$ 2.5 million as the minimum for the Business Investment Migrant Category and created a new potential source of immigrant entrepreneurs into New Zealand. The top 5 countries of birth of New Zealand residents in 2013 were as follows: New Zealand (74.5 percent), United Kingdom (6.4 percent), China (2.4 percent), India (1.7 percent) and Australia (1.6 percent).

According to the Auckland Chamber of Commerce (2015), more than 80 per cent of migrants who came to New Zealand, settled in Auckland. Meanwhile, Auckland also provides the most readily available specialist business services and logistics to the rest of New Zealand. It is recorded that 97 per cent of New Zealand businesses consist of a small business with fewer than 20 full-time 
employees. It is also recorded that 420,207 businesses employ five employees and below (Auckland Chamber of Commerce, 2015). Small businesses account for 40 per cent of the national economic output. A substantial majority of these businesses are in the retailing sector which predominantly involves the retailing and services sector. In this regard there is a growing number of immigrant entrepreneurs who initiate and embark on the retail business sector as an avenue to stay and live in New Zealand. Some of them are said to be coming in under the skilled migration category, however, ending up by starting up their own retail businesses. This is especially relevant to retail businesses such as grocery shops, gas stations, cafés and restaurants, souvenir shops, butcheries and some others.

In particular, Auckland is home to 33.4 per cent of the New Zealand population and while it only consists of 1.7 per cent of the total New Zealand land area, it makes a perfect location for any business opportunities. Besides being a commercial city, Auckland city has housed more than 80 percent of the new immigrants coming to New Zealand. Moreover, Auckland contributes one third of New Zealand's national workforce (Auckland Chamber of Commerce, 2015). Therefore, the arrival and presence as well as the involvement of immigrant entrepreneurs in small retailing businesses has become of growing interest to various parties such as academics, NGOs and government agencies alike.

There has not been consensus about the issues concerning immigrant entrepreneurs. The literature tends to suggest a wide range of issues affecting immigrant business success in the country of destination (Enow, 2010, Azmat \& Zutshi, 2012). This research considers issues affecting immigrant entrepreneur business success to include capital/finance, cost, training, quality and safety, competition and local authority's rules and regulations. There has not been consensus on the definition of business success in the literature either, (Marques et al., 2005; Tracey and Tan, 2000). Based on the literature reviewed (Martinez and Chernatony, 2004;), this research adopts five major items after a factor analysis has been conducted, namely; increased total revenue, increased sales turnover, increased demand, increased profit, increase in the number of employees recruited. All of these were measured from the records of the last three years. The research hypothesis is that the stated business issues confronting immigrant entrepreneurs affects their business success.

\section{Research Method}

This research project employs a qualitative approach to obtain primary data as well as quantitative sources. As for primary data research, the data was obtained through a questionnaire survey, carried out involving 262 immigrant entrepreneurs, from June to October 2015. As mentioned earlier, the respondents were basically entrepreneurs from small retail businesses in Auckland city. Thus, regarding the accessibility of data, they were identified by means of a process of quota random sampling. This research is fully based on a questionnaire survey to critically examine the immigrant entrepreneur's activity by means of a structured questionnaire containing closed-ended and open-ended questions.

The questionnaire used for this study contained three parts. The first part was focused on the business of the respondents. This part surveyed the general business profiles of the respondents, which include gender, age, academic qualification and employment, etc. The second part of the 
questionnaire included questions on the issues, business success and business prospects of the entrepreneurs. This scale consisted of 20 items that measure various dimensions of business issues and challenges, 8 items of business success and 9 items of business prospects. The respondents were asked to give their perception of their business issues and challenges, their business success, and business prospects based on a 5-point Likert scale. These numbers represent: 1-strongly disagree, 2-disagree, 3-neutral, 4-agree and 5-strongly agree. This was to allow the respondents some degree of flexibility when responding to the questions. The third section was focused on the characteristics of entrepreneurs such as age, experience, type of visa etc. The purposes of migration etc. were integrated in the last part.

All together a sample of 262 entrepreneurs in Auckland city, New Zealand was analysed using SPSS version 22. To obtain the preliminary findings of this paper, it draws mostly from a qualitative analysis.

\section{The findings}

The findings are divided into entrepreneurial, demographic and business profiles, and perception of their business success.

\subsection{Entrepreneurial, Demographic and Business Profiles}

The demographic profile of the respondents is presented in Table 1 . The majority of the respondents, consisting of 87.4 percent, are below 50 years of age of whom 63.3 percent are less than 40 years old. The finding reflects a relatively young age of entrepreneurs who still have time and energy to grow and develop their businesses. Regarding the gender of entrepreneurs, 63 percent are male while 37 percent are female, indicating relatively more male immigrant entrepreneurs than female into New Zealand. In terms of educational level, 40.5 percent of the respondents have a diploma or higher degree, with 22.5 percent and 21.4 percent having a first degree and postgraduate diploma respectively. The results indicate that the small retail businesses are run by relatively educated entrepreneurs, in line with some of the earlier research findings of Wadhwa, Saxenian, Rissing, \& Gereffi (2007), and Alam and Hoque (2010).

The study found the largest number of entrepreneurs entered New Zealand through the business visa category, i.e. 30.5 percent as compared to the skilled migration category (24.4 percent), family migration (16.8 percent) and working visa (12.2 percent). This findings signal that business migration to New Zealand is confined to the second pathway of migration discussed in the earlier part of the literature survey. This category of entrepreneurs came to the country of destination with a specific purpose and skills to initially develop and expand their businesses, supporting the earlier findings of Zolin \& Schlosser (2013). The survey data shows 34.7 percent of the entrepreneurs have the same line of business experience in New Zealand to what they used to have in their country of origin. Combined with the different areas of business experience, it is observed that a total of 60.7 percent of the immigrant entrepreneurs have previous business experience prior to starting up their business presence in New Zealand. The findings further verify the migratory business category of entrepreneurs in New Zealand underlined by the earlier evidence of Wadhwa, Saxenian, Rissing, \& Gereffi (2007). 
Table 1: Selected Profile of Immigrant Entrepreneurs and Their Enterprises

\begin{tabular}{|l|l|l|}
\hline Entrepreneur profile & No & Percentage \% \\
\hline Gender & & \\
Male & 165 & 63 \\
Female & 97 & 37 \\
Total & 262 & 100 \\
\hline Migration Category & & \\
Business migration & 80 & 30.5 \\
Skilled migration & 64 & 24.4 \\
Family migration & 44 & 16.8 \\
Working visa & 32 & 12.2 \\
Student visa migration & 18 & 6.9 \\
Others & 24 & 9.2 \\
Total & & 100.0 \\
\hline Business Experience & & \\
Same business experience & 91 & 34.7 \\
Different business experience & 68 & 26.0 \\
No business experience & 103 & 39.3 \\
Total & 262 & 100.0 \\
\hline Country of Origin & & \\
\hline China & 88 & 33.6 \\
India & 84 & 32.1 \\
South Korea & 21 & 8.0 \\
Thailand & 7 & 2.7 \\
United Kingdom & 8 & 3.1 \\
Other European & 8 & 3.1 \\
Fiji & 11 & 4.2 \\
Philippines & 2 & 0.8 \\
Others (Asian/lslanders) & 33 & 12.6 \\
Total & 262 & 100.0 \\
\hline Background of Enterprises & No & Percent \\
\hline Size of Enterprise (by Employment Size) & & \\
\hline Fewer than 5 employees & 149 & 56.9 \\
5 to 9 employees & 90 & 34.4 \\
10 employees and more & 23 & 8.7 \\
Total & & 100 \\
\hline Sources of Started up Capital & & \\
Personal capital & 203 & 77.5 \\
Relatives & 40 & 15.2 \\
Others (friends, fellow country etc.) & 19 & 7.2 \\
Total & 262 & 100.0 \\
& & \\
\hline
\end{tabular}


Meanwhile, the country of origin of the entrepreneurs was found to include diverse nationalities. Entrepreneurs from China score the highest with 33.6 percent, followed closely by entrepreneurs from India who consist of 32.1 percent and South Korea who make up another 8 percent. Interestingly, those entrepreneurs from the United Kingdom and other European nations share a smaller percentage of 3.1 percent respectively. The findings reveal more Asians, particularly Chinese and Indians than European entrepreneurs to be immigrants to New Zealand. This finding could be explained by the Immigration Act of 1987, resulting in the emergence of immigrants who come from non-traditional sources, particularly from Asia and other parts of the world. The findings prove that the review of the Act in 1987 for the preference of migrants has not only resulted in an increase of Asian skilled migrants, but it also has significantly affected more business migration especially from China and India.

The main types of retail business found in the survey are food and beverages comprising 25.1 percent, while petro kiosks, clothing and apparel and souvenir shops respectively consist of 16 percent, 10.3 percent and 9.9 percent. The size of their enterprise by the number of employees shows that the majority of them (56.9 percent) are employing fewer than 5 , while 34.4 percent of the enterprises have 5 to 9 employees. Most of the enterprises included in the survey have been in business for more than seven years (32.4 percent), and another 29 percent has been in business between one to 3 years. In terms of initial start-up sources of capital, finance by personal savings (77.4 percent) is found to be at the top of the list followed by relatives (15.2 percent). This finding confirms some of the earlier evidence of Marger \& Hoffman (1992), Fairlie (2008) Hart \& Acs (2011) who emphasised further that family and friend networks extended to fellow countrymen provide a much more comfortable environment to immigrant entrepreneurs, in addition to raising capital for the starting up stage of a business.

\subsection{Perceived Business Issues and Success}

As discussed in the research method, the respondents were asked to give their perception of their business issues, and their business success, based on a 5-point Likert scale. These numbers represent: 1-strongly disagree, 2-disagree, 3-neutral, 4-agree and 5-strongly agree. As the data are derived from the perception of respondents, i.e. immigrant entrepreneurs perceived business issues and success, they are tested for their consistency by the Cronbach alpha. The result is found to be very high, i.e. 931 for business issues and .945 for business success. The values of Cronbach's alpha " $\alpha$ " range all are above 0.7 , hence confirming the reliability and internal consistency of the underlying items in the research (see Table 2).

Table 2: Reliability Analysis for Business Issues and Business Success

\begin{tabular}{|l|l|l|}
\hline No of Item & No of Items & Cronbach's Alpha Value \\
\hline Business Issues & 20 & .931 \\
\hline Business Success & 8 & .945 \\
\hline
\end{tabular}

Moreover, Table 3 shows that immigrant entrepreneurs perceive their business success positively in the light of the mean values indicated. All eight business success indicators have the mean values 
above 2.94 out of the value five on the Likert scale. Since the Likert scale started from "strongly disagree" (1) to "strongly agree" (5), the higher the mean score, the greater the business success being realised, whereas the lesser the value of the standard deviation, the more meaningful the finding is, as its value is closer to the mean score (centrality).

Table 3: Perceived Business Success

\begin{tabular}{|c|l|c|c|}
\hline No & \multicolumn{1}{|c|}{ Item of Business Success } & Mean & $\begin{array}{c}\text { Standard } \\
\text { Deviation }\end{array}$ \\
\hline 1 & $\begin{array}{l}\text { Our sale turnover has increased over the past three } \\
\text { years }\end{array}$ & 3.34 & 1.300 \\
\hline 2 & $\begin{array}{l}\text { Our total revenue has increased over the past three } \\
\text { years. }\end{array}$ & 3.35 & 1.289 \\
\hline 3 & $\begin{array}{l}\text { Our profit margin has increased over the past three } \\
\text { years. }\end{array}$ & 3.16 & 1.352 \\
\hline 4 & $\begin{array}{l}\text { Our market share has increased over the past three } \\
\text { years. }\end{array}$ & 3.09 & 1.324 \\
\hline 5 & $\begin{array}{l}\text { The demand for the products made by our company } \\
\text { has increased over the past three years. }\end{array}$ & 3.20 & 1.378 \\
\hline 6 & $\begin{array}{l}\text { Our cost per unit of product sold has decreased over } \\
\text { the past three years }\end{array}$ & 2.70 & 1.300 \\
\hline 7 & $\begin{array}{l}\text { The number of employees has increased in our } \\
\text { business over the past three years. }\end{array}$ & 2.94 & 1.456 \\
\hline 8 & $\begin{array}{l}\text { Our total revenue has increased over the past three } \\
\text { years. }\end{array}$ & 3.33 & 1.351 \\
\hline
\end{tabular}

Furthermore, this research extended its analysis to explore the relationship between business issues and business success through a simple direct one-way analysis or ANOVA. It is a preliminary attempt to evaluate business issues affecting the business success among immigrant entrepreneurs in New Zealand. Independent variables are 20 items of business issues and dependent variables are 8 items of business success.

Table 4 reveals that the $R$ Square is 0.556 indicating that 55.6 percent of the variance can be predicted from the independent variables that affect dependent variables. The relationship is highly significant as the $p$ value at 0.00 is much less than $p=<0.05$ for a 95 percent confidence level, validating the hypothesis of the research. In short, the items in the business issues are considered to be essential in determining business success of immigrant entrepreneurs in New Zealand. The findings provide further proof and evidence found by earlier researches, especially the study of Bates (1999), who found a similar result. Earlier scholars who gave due recognition to the establishment and expansion of new small businesses in a country such as Lin (2015), and RibeiroSoriano \& Mas-Verdú (2015) are supported by the findings. In order to attain long term economic growth, the involvement of entrepreneurs is also essential (Forsman, 2011) and immigrant entrepreneurs are not an exception to this. 
Table 4: Model Summary

\begin{tabular}{|l|l|r|r|r|r|}
\hline Model & $\mathrm{R}$ & $\mathrm{R}$ Square & $\begin{array}{c}\text { Adjusted R } \\
\text { Square }\end{array}$ & $\begin{array}{c}\text { Std. Error of } \\
\text { the Estimate }\end{array}$ & \multicolumn{1}{c|}{ Sig. } \\
\hline 1 & $.556^{\mathrm{a}}$ & .309 & .255 & 7.885 & .000 \\
\hline
\end{tabular}

\section{Summary and Conclusion}

The research endorses a certain immigrant entrepreneurial profile and their enterprises in New Zealand. The findings also conclude that there are specific issues in businesses that positively contribute to business success by immigrant entrepreneurs. In line with this, the study emphasises that with the increase in the business success, there is higher overall growth of small businesses in which the immigrant entrepreneurs are involved. The study thus highlights that giving opportunities to immigrant entrepreneurs would potentially contribute to economic growth activities in New Zealand.

Through this finding, it is clear that immigrant entrepreneurs can be a great source of entrepreneurial development and future economic impetus to the country concerned. This is related to the United Nations Report on International Migration and Development 2013 (UN 2013). Moreover, the evidence provided by Lin (2015), Ribeiro-Soriano \& Mas-Verdú (2015) who gave due recognition to establishment and expansion of new small businesses in a country through immigrant entrepreneurs are validated by these findings. In short, the study concludes that immigrant entrepreneurs can be an essential source of attaining long term economic growth in a country. The findings of this research are indeed meaningful for the relevant development authorities to take the necessary steps to outline a new and productive content for potential entrepreneurial development in New Zealand in future.

\section{References}

Auckland Chamber of Commerce 2015. Auckland Business Report, Auckland, New Zealand.

Alam, G. M., and Hoque, K. E. 2010. Who gains from "Brain and Body Drain" BusinessDeveloping/developed world or individuals: A comparative study between skilled and semi/unskilled emigrants. Afr. J. Bus. Manage, 4(4), 534-548.

Azmat, F., and Zutshi, A. 2012. Influence of home-country culture and regulatory environment on corporate social responsibility perceptions: The case of Sri Lankan immigrant entrepreneurs. Thunderbird International Business Review, 54(1), 15-27.

Bates, T. 1999. Existing self-employment: an analysis of Asian immigrant-owned small businesses. Small business economics, 13(3), 171-183.

Enow, M. 2010. Immigrant Entrepreneurship: Case studies of challenges faced by immigrant entrepreneurs in a large and small Swedish city. MBA Thesis. Jonkoping International Buisness School, Jonkoping University, Sweden.

Fairlie, R. W. 1999. The absence of the African-American owned business: an analysis of the dynamics of self-employment, Journal of Labour Economics, 17, 80-108. 
Forsman, H. 2011. Innovation capacity and innovation development in small enterprises. A comparison between the manufacturing and service sectors. Research Policy, 40(5), 739750. doi: http://dx.doi.org/10.1016/j.respol.2011.02.003.

Hart, D. M., and Acs, Z. J. 2011. High-tech immigrant entrepreneurship in the United States. Economic Development Quarterly, 25(2), 116-129.

Kloosterman, R., Van der Leun, J., and Rath, J. 1998. Across the border: Immigrants' economic opportunities, social capital and informal business activities. Journal of ethnic and migration studies, 24(2), 249-268.

Lin, A. A. 2015. Splitting the EB-5 Program: A Proposal for Employment-Based Immigration Reform to Better Target Immigrant Entrepreneurs and Investors. Chapman Law Review, 18, 527577.

Marger, M .N., and Hoffman, C. A. 1992. Ethnic enterprise in Ontario: Immigrant participation in the small business sector. International Migration Review, 968-981.

Martinez, E. and Chernatony, L. 2004. The effect of brand extension strategies upon brand image. Journal of Consumer Marketing, 21(1): 39-50.

Marques, D. P., Narangajavana, Y., and Simon, F. J. (2005). Competitive strategies and performance in Spanish hospitality firms. International Journal of Contemporary Hospitality Management, 17 (1): 22-38

Martinez, E. and Chernatony, L. 2004. The effect of brand extension strategies upon brand image. Journal of Consumer Marketing, 21 (1): 39-50.

Nahapiet, J., and Ghoshal, S. 1998. Social capital, intellectual capital, and the organizational advantage. Academy of management review, 23(2), 242-266.

ibeiro-Soriano, D., and Mas-Verdú, F. 2015. Special Issue on: Small business and entrepreneurship: their role in economic and social development. Entrepreneurship \& Regional Development, 1-3. doi: 10.1080/08985626.2015.1041252.

Tracy, B. 2000. The 21 Success Secrets of Self-made Millionaires: How to Achieve Financial Independence Faster and Easier Than You Ever Thought Possible. Berrett-Koehler Publishers.

United Nations (UN). 2013. Report on International Migration and Development, UN, New York.

Yu, X. 2014. Entrepreneurship of Foreigners in Kuopio Region. Degree Programme in International Business Bachelor's Thesis, Savonia University of Applied Sciences. Wadhwa, V., Saxenian, A., Rissing, B. A., \& Gereffi, G. 2007. America's new Immigrant entrepreneurs: Part I. Duke Science, Technology \& Innovation Paper(23).

Waldinger, R., Ward, R., and Aldrich, H. E. 2000. Ethnic entrepreneurs. Entrepreneurship: The social science view, 356-388.

Zolin, R., and Schlosser, F. 2013. Characteristics of immigrant entrepreneurs and their involvement in international new ventures. Thunderbird International Business Review, 55(3), 271-284. 